\title{
帯電防止剤の表面配列とその作用機構†
}

(昭和 40 年 6 月 28 日 受 理)

\author{
丸茂 秀雄・高 井誠*
}

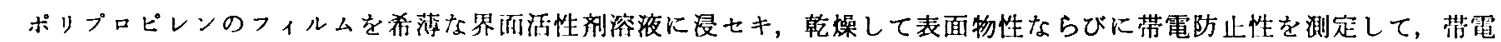

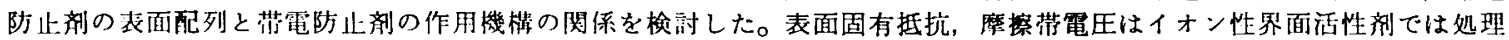
濃度によって変曲点を生じて，極大，極小が現われた。接触角からみて，この逆転は表面の分子周の配列の近転によるも のと考えられる。带電防止性は処理溶液の電尊度とは直接的関係はなく，水溶性界面活性剤の帯電防止性は相対湿度の影

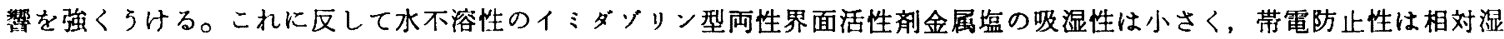
度の影䈏をうけないようであり,すぐれた性能を示す。この金属塩は誘電率の異なる有機溶剤の溶液で処理した場合には, 唀電寗の高い有機溶剂の昜合の方か，带電防止性はよいので, 表面の分子䅉の配列は空気侧に極性基を向けた場合が，そ うでない場命よりすぐれていると考充られる。

\section{1 鍺旁}

前報1では队部用州電防耻剂を練り込んたポリエチレンの表面 分析を行なって，樹脂と相溶性がないと考えられるアルキルアミ ンの酸化ェチレン付加休では, 時問経過とともに表面濃度は無制 限に增大するに反して，雨性界面活性剂金属塩では，表面を洗沵 した後の経日では, 表面濃度はある濃度までは增大するがそれ以 後は一定の值をとっていて，これらの值が表固有抵抗に対応して

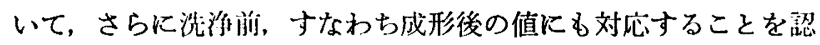
めた。これらのことから, 著者らは単分子尿の表面での形成を推 祭し得た。本報ではひきつついて，表面の分子㙕がどんな配列を しているかを検討し，これらの知見と堆電防止剂の俳用機棈を絬 びつけようと武みた。

\section{2 結果および考察}

\section{$2 \cdot 1$ 吸着と帯電防止性}

第 1 報 2 では齐種界面活性剂の此較的高い濃度の水溶液にブラ スチックを浸セキして，外部用带電防止剂としての性能を検討し た。外部用率電止剂は外部から物体表面に付着されるものである から，単に吸着という界而化学的现象を考总ても，最も単純な水 溶液に浸セキ，乾燥する㧜をとる場令でも，水溶液に扣ける吸 羞, 乾燥後の表而に打ける吸 符があり, 複雑である。これ らの外部用带電防止剂の作用 機構については丸茂が既に諳 しい論議をしている゙๋。

Graham4) が莎霆防归剂と してはあまり効果がないオレ イン酸熄について, 带霆䏚》:

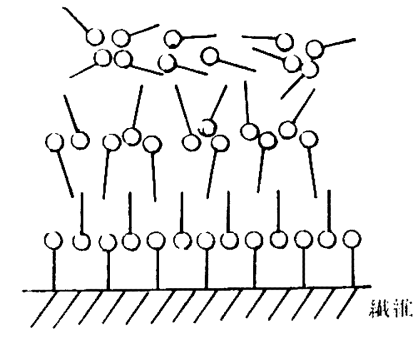

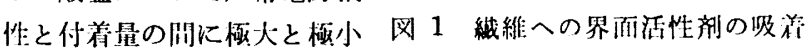
が交互に特こって，逆転しながら，しだいに州電防性がよくな ることを発化して以米，Bühler ${ }^{5)}$, Rath $^{6)}$, Steiger) らむ水溶液

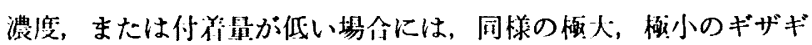

†本献を「带電防止绪に関する研究（第9 報)!とする.

* Hideo MARUMO, Makoto TAKAI ライ†: 油脂侎式食

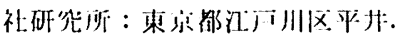

1) 丸茂，泊非，工化 68，2209 (1965)。

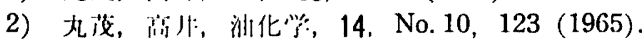

3) 丸淺, 测惦 17, No. 1, 81 (1964).
ザ模栚が，四にあらわれることを示した。 Graham ${ }^{4)}, \mathrm{Rath}^{6)}$, Bühler ${ }^{5)}$ らは，この原因は図 1 のよ5に分子曽の配列が近になっ て，遂には等方吽の状欵になるので，带電防止性が低濃度，低付 洋量では極大，極小が現われて，高濃度，高付等量ではそれらが 现われなくなると考えている。Steiger ${ }^{7)}$ は界面活性剂の 化学模 造の対称性に原因があるとしている。

表 1 の，本報までに取扱ってきた各種の界面活性剂は，水に不 溶性のものがあるのでエタノール溶液とし，これにポリプロピレ ンのフィルムを 30 秒浸セキした後, 風乾して表面固有抵抗, 糜 擦带電压を测定した絬果を表 2 に示す。

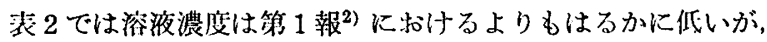
概して，㤗面固有抵抗は，アルキルアミンの酸化エチレン付加休 (No. 56)，アラニン型两性界面活性剂 Ca 墔 (No. 153，173, 193), $\mathrm{C}_{7} \mathrm{H}_{15}$ のアルキル基をもつイミダゾリン型雨性界面活性剂 $\mathrm{Ca}$ 塩 (No. 393) では比較的高くなっている。No. 56 を除いて, 表 2 では $0.03 \%$ 濃度の 表面固有抵抗の值が $0.015,0.05 \%$ の 場合よりも高くなっていて, 濃度に対して極大傎の存在を示して いる。摩摖带電下は图2 2 よ5に表面国有抵抗とは比例威係にむ

表 1 界面 活 性 剂

\begin{tabular}{|c|c|c|c|}
\hline 䃔性刘 No. & & 化 & 權 \\
\hline 25 & & \multicolumn{2}{|c|}{ ラウリルトリメチルフンモニウムクロリド } \\
\hline 26 & & \multirow{2}{*}{\multicolumn{2}{|c|}{ 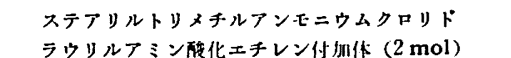 }} \\
\hline 56 & & & \\
\hline 153 & & \multicolumn{2}{|c|}{ 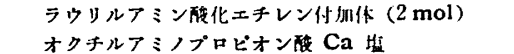 } \\
\hline 173 & & \multicolumn{2}{|c|}{ ラウリルアミノプロピオン亚 Ca } \\
\hline 186 & & \multicolumn{2}{|c|}{ ラウリルフミノブロピオン酸 Na Hi } \\
\hline 193 & & \multicolumn{2}{|c|}{ ステアリルアミノプロピオン慗 $\mathrm{Ca}$ 垃 } \\
\hline 273 & $\mathrm{R}: \mathrm{C}_{11} \mathrm{H}_{23}$ & , $\mathrm{Ca}$ 塭 & \multirow[b]{2}{*}{$\mathrm{R} \cdot \mathrm{CONHCH}_{2} \mathrm{CH}_{2} \mathrm{NCH}_{2} \mathrm{CH}_{2} \mathrm{OH}$} \\
\hline 293 & & $\mathrm{Ca}$ 垃 & \\
\hline 305 & $\mathrm{R}: \mathrm{C}_{27} \mathrm{H}_{35}$ & $\begin{array}{l}\text { ツピッテ } \\
\text { ルイオン }\end{array}$ & $\mathrm{CH}_{2} \mathrm{COO}$ \\
\hline 393 & $\mathrm{R}: \mathrm{C}_{7} \mathrm{H}_{15}$ & Ca 塩 & \\
\hline 413 & $\mathrm{R}: \mathrm{C}_{12} \mathrm{H}_{23}$ & $\mathrm{Ca}$ 垃 & \\
\hline 431 । & & $\mathbf{M g}$ 战 & \\
\hline 432 & & Al 醏 & \\
\hline 433 & & $\mathrm{Ca}$ & $\mathrm{N}-\mathrm{CH}_{2}$ \\
\hline 434 & $\mathrm{R}: \mathrm{C}_{17} \mathrm{H}_{35}$ & Mn $H_{i}$ & $\mathrm{HO}^{\prime} \mid \mathrm{CH}_{2} \mathrm{CH}_{2} \mathrm{OH}$ \\
\hline 443 & & $\mathrm{~Pb}$ 增 & $\left(\mathrm{CH}_{2} \mathrm{COO}\right)$ \\
\hline 445 & & $\begin{array}{l}\text { \%ビッテ } \\
\text { ルイオン }\end{array}$ & \\
\hline 446 & & Na 㙁 & \\
\hline
\end{tabular}

4) G. W. Graham, Nature 168, 781 (1951).

5) M. Bühler, Textil-Praxis 12, 1142 (1957).

6) H. Rath, M. Bühler, P.Senner, Reyon, Zellwolle u. chemie-fasern 7, 549 (1961).

7) F.H. Steiger, Textile Research J. 27, 721 (1958). 
表 2 各種界面活性剂の带電防止性

\begin{tabular}{|c|c|c|c|c|c|c|}
\hline \multirow{3}{*}{$\begin{array}{c}\text { 活性剈 } \\
\text { No. }\end{array}$} & \multicolumn{3}{|c|}{ 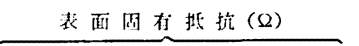 } & \multicolumn{3}{|c|}{ 磨摖带軍压 (V) } \\
\hline & \multicolumn{3}{|c|}{ エタノール溶淮治度 $(\%)$} & \multicolumn{3}{|c|}{ 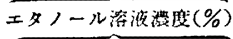 } \\
\hline & 0.015 & 0.03 & 0.05 & 0.015 & 0.03 & 0.05 \\
\hline 空試䲆 & $>10^{16}$ & & & 3500 & & \\
\hline 25 & $6.0 \times 10^{10}$ & $3.5 \times 10^{11}$ & $3.8 \times 10^{10}$ & 53 & 80 & - \\
\hline 26 & $4.2 "$ & $7.5 \times 10^{10}$ & $8.0 \times 10^{\circ}$ & 50 & 15 & 20 \\
\hline 56 & $1.2 \times 10^{12}$ & $3.3 \times 10^{11}$ & $1.2 \times 10^{11}$ & 190 & 130 & 65 \\
\hline 153 & $1.6 "$ & $5.0 \times 10^{12}$ & $1.0 \times 10^{12}$ & 160 & 160 & 110 \\
\hline 173 & $6.0 \times 10^{11}$ & $6.0 "$ & $3.0 "$ & 150 & 160 & 100 \\
\hline 193 & $2.0 " 11$ & $2.0 "$ & $1.0 \%$ & 120 & 150 & 90 \\
\hline 273 & $3.0 \times 10^{10}$ & $6.0 \times 10^{11}$ & $1.0 \times 10^{10}$ & 50 & 120 & 50 \\
\hline 293 & $6.0 \times 10^{9}$ & $5.4 \prime \prime$ & $4.0 "$ & 45 & 110 & 50 \\
\hline 393 & 3. $0 \times 10^{12}$ & $8.0 \times 10^{12}$ & $6.0 \times 10^{11}$ & 110 & 170 & 95 \\
\hline 413 & $7.0 \times 10^{11}$ & $4.0 "$ & $8.0 \times 10^{10}$ & 80 & 170 & 70 \\
\hline 431 & $4.5 \mathrm{\prime \prime}$ & $2.0 \times 10^{13}$ & $9.0 "$ & 120 & 150 & 80 \\
\hline 432 & 4. $0 \times 10^{11}$ & $3.0 \times 10^{12}$ & $9.0 \times 10^{0}$ & 95 & 160 & 70 \\
\hline 433 & $6.5 \times 10^{10}$ & $2.0 "$ & $5.0 "$ & 60 & 110 & 50 \\
\hline 434 & $9.0 \times 10^{11}$ & $4.0 \times 10^{13}$ & $1.0 "$ & 100 & 180 & 60 \\
\hline 443 & $4.2 "$ & $5.0 \times 10^{12}$ & 4. $2 \times 10^{10}$ & 90 & 140 & 75 \\
\hline 445 & $5.0 \times 10^{10}$ & $4.0 \times 10^{13}$ & $2.0 \times 10^{9}$ & 70 & 190 & 40 \\
\hline 446 & $3.0 "$ & $2.0 \times 10^{13}$ & $1.5 "$ & 60 & 115 & 40 \\
\hline
\end{tabular}

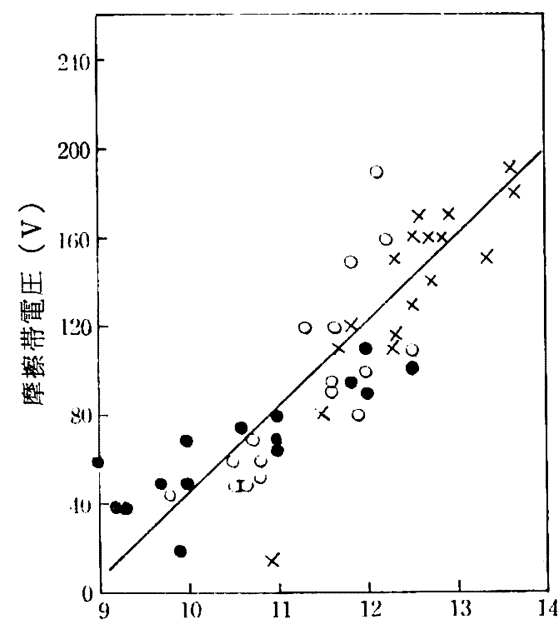

表面固有抵抗の対数 $(\Omega)$

図 2 摩擦带電压と表面固有抵抗

$0: 0.015 \% \quad x: 0.03 \%$

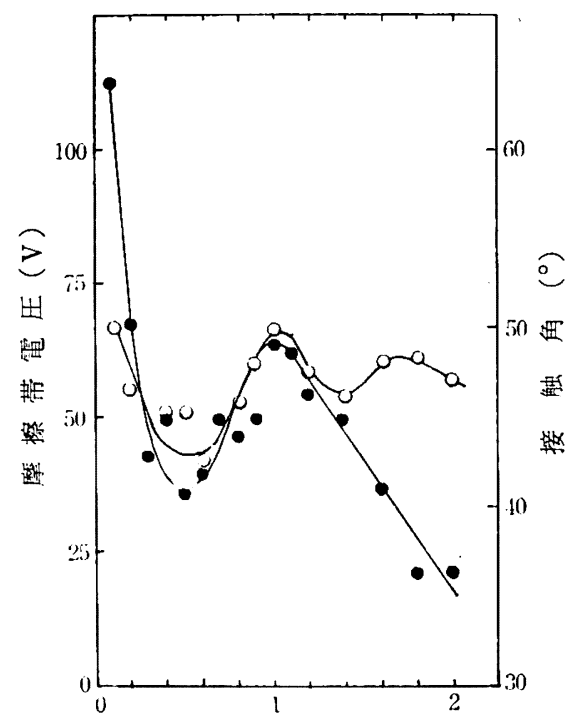

処理济液濃度 $\left(10^{-3} \mathrm{~mol} / \mathrm{l}\right)$

成3 No. 26 で処理したポりプロピレンのフィルムの表而物吽

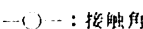

るが，表面固有抵抗の場合と同様に溶液濃度によって極大值が存 在している。このような極大值の存在は, 前述研究者らの知見と 一致している。

な打表 2 の表面固有抵抗，摩擦带電厄は，今までに（第 2 報8） から）のべてきた内部用带電防剂として优用の場命の值と対応 し得るものである。

次に，著者らは同じポリプロピレンフィルムを低い濃度のエタ ノール溶液（No. 26，445）に没セキ，谠燥して摩摖带電压，接 触角を測定して図 3, 図 4 を得た。図 5 では浴液濃度の美からの 吸着量と, 処理溶液の電獐度を示してある。

No. 26 の場合には溶液濃度とともに吸着量は確邦に增大して いるが，摩摖带電非には尛と同様の極大，極小が現われている。

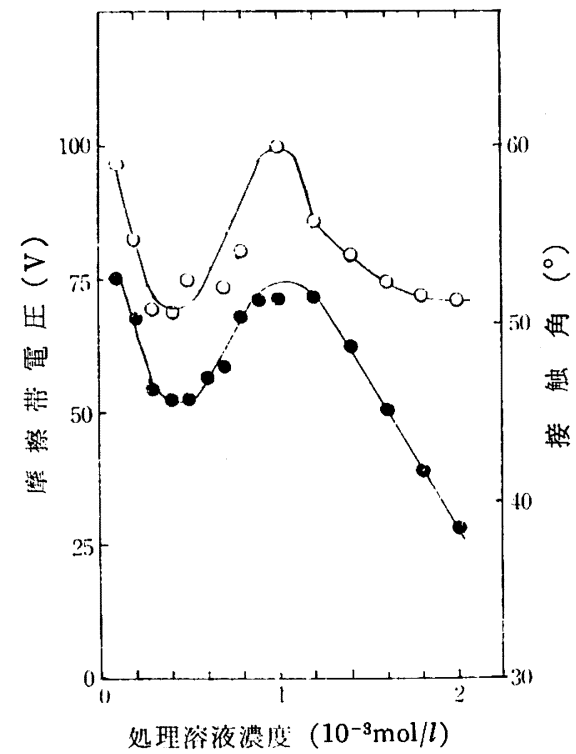

䦌4 No. 445 で処理したポリプロピレンのフィルムの表面物性

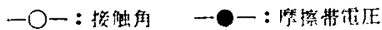

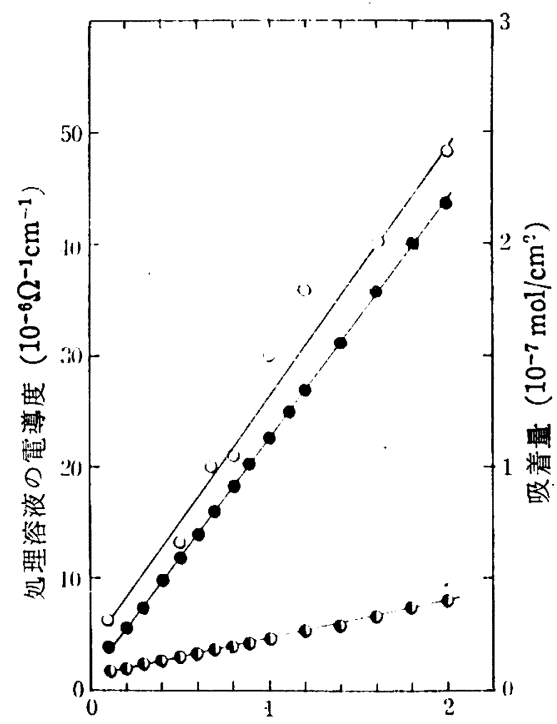

処理溶液濃度 $\left(10^{-3} \mathrm{~mol} / l\right)$

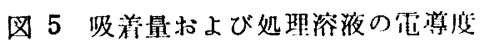

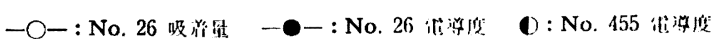

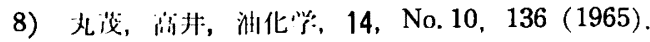


接触角は摩擦帯電压と比例して高低がある。No. 445 でも同様で ある。接触角は表面に配列した分子層の極性基の力向を示してい るので，図 1 に抮ける分子層の方向の逆転を考えると，上記の現 象は明らかに説明できよ5。つまり帯電防止性は極性基が空気側 を向いた表面配列の場命が，そうでない場合よりもすぐれている と結論できる。このような表面配列は表而に值立した形をとるイ オン性界面活性剂の場合に考察されるのであり，非イオン界面活 珄剂, またはこれに近いアミン酸化ェチレン付加体では, 直立し た吸着よりは，むしろ横になった形が考えられるので適当でな い。表 2 の No. 56 はこの例である。

\section{$2 \cdot 2$ 溶液の電尊度と帯電防止性}

Henshall9) は外部用帯電防止剂の水溶液で 䋐維を処理する場 合には，水溶夜の電導度は带電防止性とは無関係であることを示 している。㘠 5 では No. 26, 445 のエタノール溶液の電導度を 示すが， No. 26 と No. 445 では大きな养があるにもかかわら

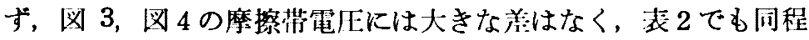
度の燕電防止性が示されている。即ち，Henshall9) の見解と一 致する結果が得られている。つまり带電防止性は䔩嬠したプラス チック，または織維の表面の電導度，換言すれば表面固有抵抗に は密接な関係はあるが, 処理溶液白身の電導度とは無関係である。

\section{$2 \cdot 3$ 吸湿性之带電防止性}

㵶維, プラスチックが相対湿度の影響をうけて表面固有抵抗と 相対湿度，または含水薪と密接な成係のあることは丸茂が別に紹 介している(10)。しかし，合成瀻維，プラスチックでは，相対湿度 のみの調節によって带電防止が可能な程度まで表面固有抵抗をさ げることは不可能である。古くから带医防止剂の作用機满は，表 面に付着して空気中から水分を吸収して，泰面の電薄性を高める ためと云われてきたが，グリセリン，ボリエチレングリコールな

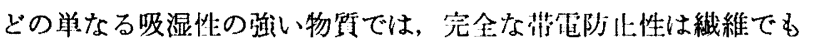
発揮されないことは Henshal19) その他の研究者が示している。

Henshall9) は吸湿性は率電防江:剂の作用機構では支配的な要 因でないことを考察し，Bühler ${ }^{5)}$, Rath' ${ }^{6)}$ らも同㥞の考察を行な ってむしろ2.1で述べたような界面化学的な吸着が支配的であ ると言っている。

著者らは表 1 の界面活性郕の吸湿性を調べて䘚 3 を得た。力 チオン界面活性剤は落しく高い吸湿性を示すが， No. 393，413 を除いて両性界面活性剂の Ca 塩は低い含水率しか示さず, $\mathrm{Mg}$,

表 3 各種界面活性剂の含水率

$\begin{array}{rccc}\text { 活性: } \begin{array}{c}\text { 淤 } \\ \text { No. }\end{array} & \text { RH } 42 \% & \text { RH } 65 \% & \text { RH } 88 \% \\ 25 & 14.6 & 32.4 & 53.1 \\ 26 & 3.8 & 12.8 & 22.9 \\ 56 & 1.0 & 5.2 & 14.1 \\ 153 & 1.1 & 5.8 & 9.1 \\ 193 & 1.0 & 3.5 & 6.3 \\ 273 & 1.1 & 4.2 & 8.7 \\ 293 & 1.0 & 2.4 & 6.0 \\ 393 & 6.7 & 18.6 & 27.6 \\ 413 & 2.1 & 11.8 & 23.4 \\ 431 & 4.8 & 16.1 & 27.8 \\ 432 & 2.9 & 11.9 & 23.0 \\ 433 & 1.6 & 6.5 & 8.7 \\ 434 & 2.7 & 7.4 & 14.0 \\ 442 & 4.6 & 15.7 & 23.8 \\ 445 & 3.6 & 9.8 & 14.9\end{array}$

9) A. E. Henshall, J. Soc. Dyers Colourists 76, 525(1960).

10) 丸议, 油版 16, No. 11, 80 (1963).
$\mathrm{Al}$ 塩はかなり高い含水率を示している。 No. 431, 432 の $\mathrm{Mg}$, Al 塩はかなり吸湿性は強いが，これが結晶水と閔係あるかど かは調べていない。付加モルの低いNo. 56 扣よび両性界面活性 剂のッビッテルイオン No. 445 は上記の中間に位置している。

さらに装 3 から数種 をえらんで, 濃度 $2 \times$ $10^{-4} \mathrm{~mol} / l$ のエタノー ル溶液をつくり,ポリ プロピレンのフィルム を 30 秒浸七キして風 晾した後，各種の相対 湿度の環境に扣いて, 表面固有抵抗を測定し た。結果は図 6 のよう である。水溶性のカチ オン界面活性㓲 No.

26, アルキルアミンの 酸化エチレン付加体 No. 56 では, 泰面固

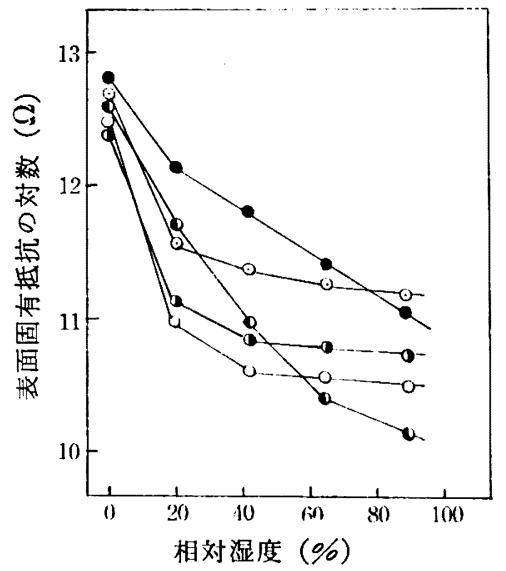

図 6 相対湿度と表面固有抵抗 $2 \times 10^{-4} \mathrm{~mol} / l$ エタノール溶波で処理 D: $26, \bigcirc: 56, \odot: 393, \bigcirc: 413, \bigcirc: 433$ 有抵抗は相刘湿度の増大とともに低下していて，明らかに相対湿 度の影響をうけている。しかし，イミダゾリン型両性界面活性剈 Ca 塩の No. 393，413，433 は相対湿度 40\% まではその影響を 5けるが，それ以上ではほぼ一定の表面固有抵抗を示していて， 相対湿度とは無関係である。つまり,これら両性界面活性剂 Ca 塩の吸湿性は帯電防止性には無関係であるとは言わないが，その 冈子よりも，むしろ，いままで本報で推察してきたように，最稠 密配列の極性基を空気側に向けた表而分子層のイオン電尊による 可能性が強い。このよ5に吸湿性にはむまり影響されない带電防 止性を示す带電防止剤は, 静電気障害そのものが低い相対湿度で 扣こりやすいので，実用面からもすぐれている。

\section{4 表面分子籍之带電防止性}

Bühler ${ }^{5)}$ は図 7 のように界面活 性㶡の吸着を説明している。水溶 性のイオン性の界面活性剂は, 水 溶夜では親水基は水中に, 柾水基 は空気側を向いて配列していて （A），濃度が增すと，しだいに疎 水基が平行して直立して配列する ようになり（B），遂には最稠密配 列（C）の形をとる。この場介, 柾水基同志は van der Waals の カでつながっている。繊維を(C) に浸セキすると，水小では（D) のよ5な吸着が扣こり，乾燥する と（E）となる。（E）の場へには Bühler ${ }^{5)}$ は指摘してないが，イオ
(A)

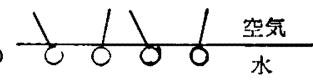

(B)

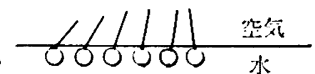

(C)

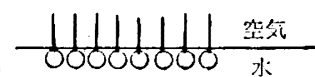

(D)

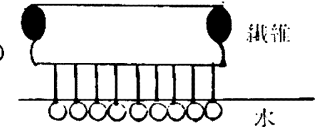

(E)

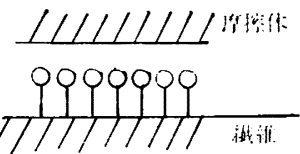

因 7 界面活性剂の吸着

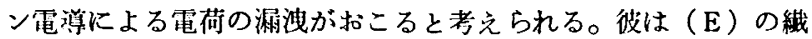
維上に配列した界面活件剂の表面分子原の存在のため, 縻擦体々 の接触时の距離が增大寸るので，発需が防止，または軽減されて 蓝電防止が行なわれると述べている。この恝味では，疎水基は压 い万が効果的である。很は Graham ${ }^{4)}$ が述べたような接触器隙

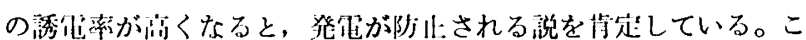


の Bühler 5) の考え方は㬰験的確認には欠けるが，帯電防止剤の 作用機構としては価値ある考察である。

著者らは表 1 の No. 186 について, 水, エタノール溶液をつ くり,ポリプロピレンのフィルムを浸セキして風乾し, 表面固有 抵抗を測定して表 4 を得た。表面固有抵抗は濃度が低いと，水溶 液では $\mathrm{pH} 2$ の場合が最も高く, $3 \times 10^{-4} \mathrm{~mol} / \mathrm{l}$ では No.186 の 等電带（pH 7.6 8.5 付近）より少し低い $\mathrm{pH} 7$ での值が高く なっている。エタノール溶液では, $3 \times 10^{-4} \mathrm{~mol} / l$ に扣ける等電

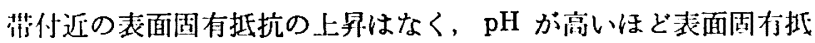
抗は低くなっている。

No. 186 は水中で鉄鋼の防錆性を与えるが，この場合にも $\mathrm{pH}$ が重大な影響を防錆性に与えていて， $\mathrm{pH}$ が高くないと効果はな (11)。No. 186 の最稠密配列に怙ける分子の占有面積の一例は表 5 のようであり ${ }^{12)}, \mathrm{pH} 12$ が最も小さく, $\mathrm{pH}$ の低下によって大 きくなっている。つまり最稠密配列が带 㷂防止性と密接な関係を示すことは，今 まで絽り返し述べてきたが，沗 5 を及る 々表面分子層の最稠密配列の稠密度合は 两性界面活性剤では $\mathrm{pH}$ と密接な関係が ありこれが表 4 の $\mathrm{pH}$ と带電防止性の 関係に重要な影嘅を与它ていると考えら れる。

菇考らは前報ならびに本報でも，带電 防止剂は外部用として使用した場合でも， 内部に練り込んだ場合でも，接触解は白 武験の值より低く，表面分子層では極性 北が空気側を向いた配列がとられている と述べるてきた。

一般に溶液の界面に拈いては，分子またはイオンの吸着は唀電 紊の高い方に極性基が向いて行なわれることは知られている。非 水系の界面化学については，まだわかっていないことが多いが,

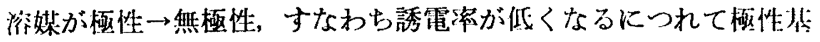
の配列の方向が逆になることが知られている ${ }^{13)}$ 。

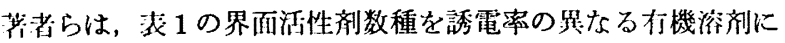
溶解して，これにポリプロピレンのフィルムを没七キし，風饭し て来面固有抵抗を测定して表 6 を得心。表6では各武料について

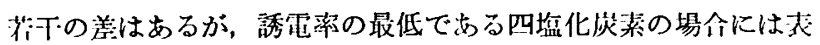

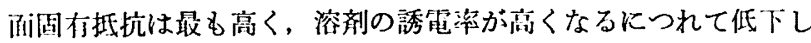
ている。つまり表面分子瘦の配列は唀電率が京い場介には, 水溶

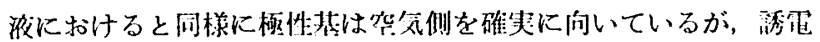
染が低くなるにつれて，このようなう向の配列がとりにくくなっ ている。はっきり萿えば州電防止剂の作用機模として極性基を究

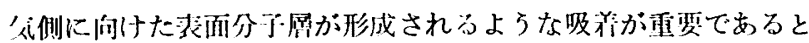
洘えられる。裴 6 のフィルムの揬触们はェタノールの場令は $50^{\circ}$ であったが，その他では 48〜65とばらばらの倠しか得ていない し，吸着昂の测定も技術的にむずかしい面も古って行なっていな いので断定はまだできていない。

11）丸茂, 高井, 未発翌。

12) K. Durkam, The 3 rd World Congress of Surface Activity B/1/3, Nr. 19 , S 130 (1960).

13) 北原, 油化" $\mathrm{s}$ : 9, $169(1960) ; 11,615$ (1962).

14）丸菠，率非，工化 68，2186 (1965).
表 4 No. 186 溶液によるポリブロピレンの帯電防止

\begin{tabular}{|c|c|c|c|}
\hline \multirow{2}{*}{ 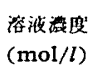 } & \multirow{2}{*}{$\mathrm{pH}$} & \multicolumn{2}{|c|}{ 表面固有抵抗 ( $(\Omega)$} \\
\hline & & 水溶液 & エタノール溶源 \\
\hline \multirow{3}{*}{$3.0 \times 10^{-4}$} & 2 & $1.2 \times 10^{10}$ & $9.0 \times 10^{12}$ \\
\hline & 7 & $1.1 \times 10^{13}$ & $6.0 \times 10^{\circ}$ \\
\hline & 12 & $6.0 \times 10^{10}$ & $4.2 \times 10^{9}$ \\
\hline \multirow{3}{*}{$6.0 \times 10^{-3}$} & 2 & $1.8 \times 10^{12}$ & $1.0 \times 10^{13}$ \\
\hline & 7 & $6.0 \times 10^{11}$ & $1.2 \times 10^{12}$ \\
\hline & 12 & $3.0 \times 10^{10}$ & $1.8 \times 10^{10}$ \\
\hline \multirow{3}{*}{$1.0 \times 10^{-3}$} & 2 & $1.2 \times 10^{12}$ & $1.5 \times 10^{11}$ \\
\hline & 7 & $2.1 \times 10^{11}$ & $1.0 \times 10^{11}$ \\
\hline & 12 & $3.0 \times 10^{10}$ & $1.5 \times 10^{10}$ \\
\hline
\end{tabular}

丧 5 No. 186 の最稒密配列に和ける分子の占有面程

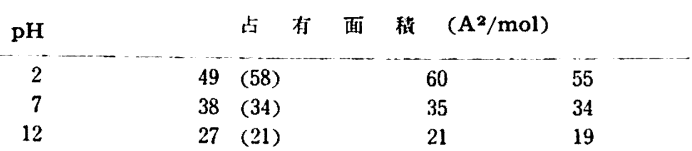

表 6 ポリプロピレンの表而固有抵抗

\begin{tabular}{|c|c|c|c|c|}
\hline 面i & 圆 & 抵 & (Q) & \\
\hline $\begin{array}{c}\text { ベンゼン } \\
(2.3)\end{array}$ & $\begin{array}{c}\text { ク口术ル } \\
(4.6)\end{array}$ & $\begin{array}{l}\text { ジクロルェタ } \\
\text { ン }(10.1)\end{array}$ & $\begin{array}{c}\text { アセトン } \\
(21.3)\end{array}$ & $\begin{array}{c}\text { × } \\
(25.8)\end{array}$ \\
\hline $4.6 \times 10^{12}$ & 4. $3 \times 10^{11}$ & $1.8 \times 10^{11}$ & $1.2 \times 10^{11}$ & $8.5 \times 10^{10}$ \\
\hline $3.2 \times 10^{12}$ & $7.4 \times 10^{11}$ & & $2.0 \times 10^{11}$ & $7.5 \times 10^{10}$ \\
\hline $2.0 \times 10^{13}$ & $6.5 \times 10^{12}$ & $2.7 \times 10^{11}$ & $8.3 \times 10^{10}$ & $6.0 \times 10^{10}$ \\
\hline $2.2 \times 10^{13}$ & $5.6 \times 10^{12}$ & 4. $0 \times 10^{11}$ & $6.0 \times 10^{10}$ & $5.3 \times 10^{10}$ \\
\hline $2.1 \times 10^{12}$ & $5.0 \times 10^{11}$ & $6.2 \times 10^{11}$ & $1.2 \times 10^{11}$ & $5.1 \times 10^{10}$ \\
\hline $\begin{array}{c}1.8 \times 10^{12} \\
\left(2.4 \times 10^{11}\right)\end{array}$ & $\begin{array}{c}1.5 \times 10^{11} \\
\left(1.7 \times 10^{11}\right)\end{array}$ & $\begin{array}{c}5.5 \times 10^{10} \\
\left(7.5 \times 10^{10}\right)\end{array}$ & $\begin{array}{c}2.5 \times 10^{10} \\
\left(6.0 \times 10^{10}\right)\end{array}$ & $\begin{array}{r}2.1 \times 10^{10} \\
\left(3.0 \times 10^{10}\right)\end{array}$ \\
\hline $\begin{array}{c}1.1 \times 10^{12} \\
\left(7.5 \times 10^{10}\right)\end{array}$ & $\begin{array}{c}1.3 \times 10^{11} \\
\left(3.0 \times 10^{10}\right)\end{array}$ & $\begin{array}{l}5.0 \times 10^{10} \\
\left(3.0 \times 10^{10}\right)\end{array}$ & $\begin{array}{c}2.5 \times 10^{10} \\
\left(2.5 \times 10^{10}\right)\end{array}$ & $\begin{array}{l}1.8 \times 10^{10} \\
\left(2.0 \times 10^{10}\right.\end{array}$ \\
\hline $\begin{array}{l}6.0 \times 10^{11} \\
\left(1.5 \times 10^{13}\right)\end{array}$ & $\begin{array}{c}7.5 \times 10^{10} \\
\left(6.0 \times 10^{11}\right)\end{array}$ & $\begin{array}{c}5.3 \times 10^{10} \\
\left(1.5 \times 10^{11}\right)\end{array}$ & $\begin{array}{l}2.7 \times 10^{10} \\
\left(9.0 \times 10^{10}\right)\end{array}$ & $\begin{array}{r}2.5 \times 10^{10} \\
\left(6.0 \times 10^{10}\right.\end{array}$ \\
\hline $\begin{array}{r}\left.5.4 \times 10^{11}\right) \\
\left(6.0 \times 10^{11}\right)\end{array}$ & $\begin{array}{l}8.5 \times 10^{10} \\
\left(1.5 \times 10^{11}\right)\end{array}$ & $\begin{array}{c}2.3 \times 10^{10} \\
\left(3.0 \times 10^{10}\right)\end{array}$ & $\begin{array}{c}9.0 \times 10^{10} \\
\left(2.5 \times 10^{10}\right)\end{array}$ & $\begin{array}{r}6.1 \times 10^{10} \\
\left(8.0 \times 10^{9}\right)\end{array}$ \\
\hline $9.0 \times 10^{11}$ & $5.5 \times 10^{11}$ & $1.3 \times 10^{11}$ & 3. $6 \times 10^{11}$ & $3.0 \times 10^{10}$ \\
\hline
\end{tabular}

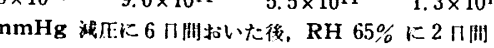

\section{3 実験}

\section{$3 \cdot 1$ 実験試料}

使用した界面活珄剂は第 1 報 ${ }^{2)}$ ，第 2 報8)，第 3 報 ${ }^{14)}$ で命成し たものである。No. 273，293，305 は脂肪酸とアミノェチルェタ ノールアミンの脱水縮合反応により得たアミド生成物を第 3 報14) と间梯に阿吽:界面涺件剂とし，さらに金属塩とし，精製したもの である。ポリプロピレンフィルムは三菱ノーブレン（三菱洲化株

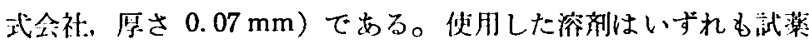
1 級を定駗䇰で精留したものである。エタノールは無水エタノー ルである。

\section{$3 \cdot 2$ 実験方法}

$3 \cdot 2 \cdot 1$ 带電防止処理 界而活件剂を水, 有機溶剂に溶解 $\mathrm{L}$, 相対湿度 $65 \%, 24^{\circ} \mathrm{C}$ に 24 㭙闬执いた後, その上澄液 $50 \mathrm{ml}$ を ビーカーにとり，背面碏 $400 \mathrm{~cm}^{2}$ のフィルムを 30 秒浸セキし た。察内で涪溜 $\left(20^{\circ} \mathrm{C}\right.$ 付近)で風乾した後, $20^{\circ} \mathrm{C}$, 相対湿度 65

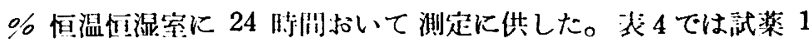
級の篮酸, カセイソーダを用いて No. 186 の水溶液の pH を調 節し、た。調節卦寺の水分の混入による濃度変化は無視した。

$3 \cdot 2 \cdot 2$ 表面固有抵抗, 糜擦帯電圧, 接触角 これらの測定に ついては第 1 報2)，第 2 報》 で報告したと同じ方法によった。た たし摩摖带它压の测定法は深田式间である。

$3 \cdot 2 \cdot 3$ 吸着量 カチオン界泊活性剂 No. 26 のポリプロピレ

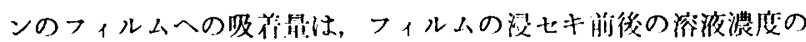
15) 深H，泊分子 8, 70 (1959). 


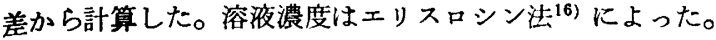

$3 \cdot 2 \cdot 4$ 電型度 No. 26, 445 のエタノール溶液の電澊度は二 ンダクトスコープ E-365（メトローム社）によった。

$3 \cdot 2 \cdot 5$ 含水來 あらかじめ陚料を真空デシケーター中で乾燥 し，さらに脱水シリカゲルのデシケーター中に 24 時間拈いて堿 量がなくなるのを確認した後, 高さ $32 \mathrm{~mm}$, 内待 $15 \mathrm{~mm}$ の科 量ビンに試料 $100 \mathrm{mg}$ をとり，72 时間冬相対湿度のもとにおい て重量增加を求めて含水率とした。各相刘湿庭は

RH 20\%：酷酸 Ca 领和水湥液

16)青木, 岩山, 楽学: 79, 522 (1959).
$42 \%$ : 硫酸 $\mathrm{Zn}$ 飽和水溶液

$65 \%$ : 酷酸 $\mathrm{Mg}$ 飽和水溶液

$88 \%$ : 熄化 $\mathrm{Ba}$ 飽和水溶夜

で調節した。な招相対湿度での表面固有抵抗の測定は上記の相対 湿度で処理したフィルムを 48 時間招いた後，相対湿度 $65 \%$, $24^{\circ} \mathrm{C}$ の恒温恒湿室でナみやかに行なった。この間のバラッキは わずかである。

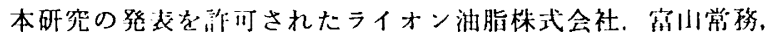

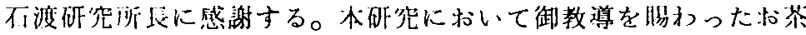

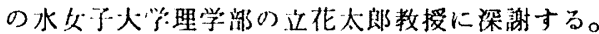

\section{$-ノ-1-$ \\ エチレンイミンとプロピレンオキシドとの 1:1 共重合におよぼす重合条件の影響十}

(昭和 40 年 5 月 21 日妥理)

\section{大城芳樹・茅田信莀・小野紀夫・阿河利男・小森三郎*}

\section{1 粕言}

エチレンイミン $(\mathrm{EI})$ とプロピレンオ证（PO）とを其重 合させた場命，コポリマーの两介佼を右するのは右をして EI であって，PO でないことは前報1,2)の絬果から畒易に想像され る。しかるにEI の単独重合に四してさえも重会度と重令条件と の関係については報告がない。そこで，一般にコポリマーの伈用 に際して，その車合度が問題となることが多いことから，EI-PO

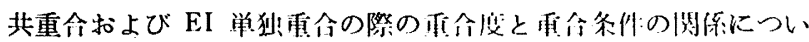
て検討した。

\section{2 実験}

\section{$2 \cdot 1$ 原 料}

$\mathrm{EI}, \mathrm{PO}$ ならびに $\mathrm{BF}_{3} \cdot \mathrm{Et}_{2} \mathrm{O}$ は亩報"と闬一のものを仙用した。

\section{$2 \cdot 2$ 共重合方法}

EI および PO をそれぞれ $0.01 \mathrm{~mol}$ ずつを内容稞 $5 \mathrm{ml}$ の封 管に入れ, 水冷後所定量の $\mathrm{BF}_{3} \cdot \mathrm{Et}_{2} \mathrm{O}$ を涙射器を川いて徐々に玔 え密封し，恒温振と5機のやでふりまぜながら $1.00 \mathrm{C} / \mathrm{min} の$

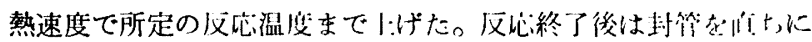

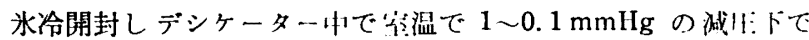
佰量になるまで板伈モノマーを除志した。得られたコボリアー

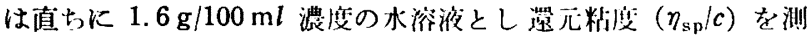

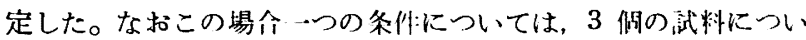
て求め平均値で示したが，それぞれの傎は 95\%。以は:の精度で . 致し再現性は良好で，またいず机の場介も雨介济は97〜100\%て

†本報を「エチレンイミンの共重合に関する研究（第 3 報）」 とする.

* Yoshiki OIISHIRO, Nobuhiko KAYAdA, Norio ONO,

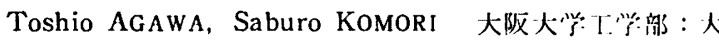
阪市都羔区、東野四。

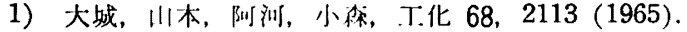

2) 大城, 川本，札本，阿汌，小标，厂化 68，2121（1965)。
あって，未反応モノマーはほとんど無視できるものと考えた。

\section{3 結 果 と 考 察}

EI-PO コポリマーの周存粘度は低跟度異学のため, $\eta_{\mathrm{sp}} / c$ 対 $c$ の咸係で，㨁線性が保たれる筙明内で，なるべく，低い濃度での $\eta_{\mathrm{sp}} / c$ により比較することとした。この際の $c$ としては, $1.6 \mathrm{~g}$ $100 \mathrm{ml}$ が適当であった。また反応温度への 加熱は殿㭙間を要し

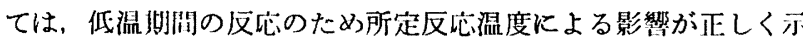
されているかどらか疑問となる。たとえば触媒量を $2.5 \mathrm{~mol} \%$ と

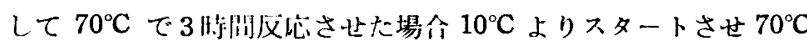
まで 60 分琹した場介のコポリマーは $\eta_{\mathrm{s}} / c=0.158$ であり，こ れに反し $70^{\circ} \mathrm{C}$ まで 2 時間かけたものでは $\eta_{\mathrm{sp}} / c=0.133$ であっ

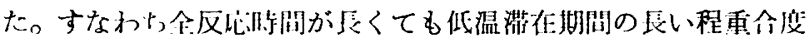
は渞加しない。したがってできるだけ低温洲在:期间を到かくする

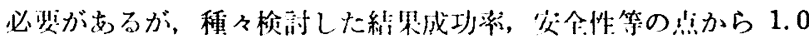

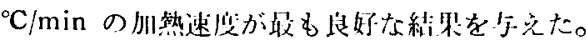

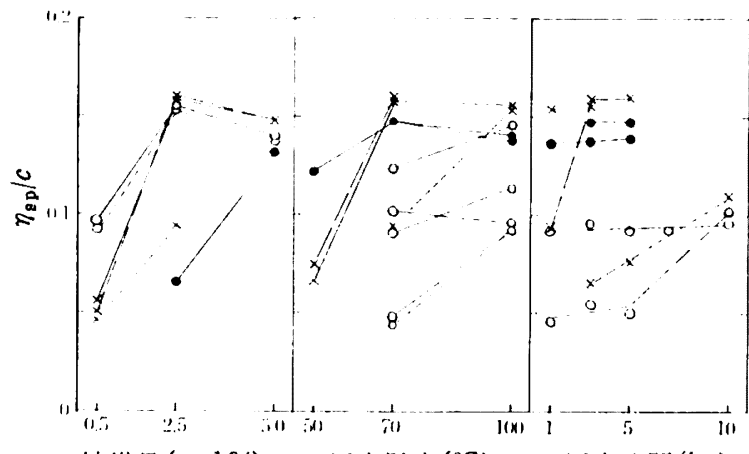

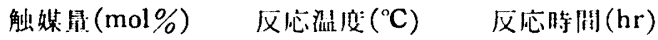

成 1 EI-PO 其雨令での而合条件の影制

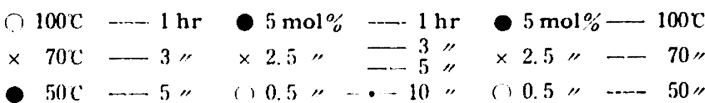

